\title{
LA CORONACIÓN DE AGUSTÍN I DE MÉXICO EN LOS SERMONES RELIGIOSOS IMPRESOS*
}

\author{
POR \\ JOSEP ESCRIG ROSA ${ }^{1}$ \\ Universitat de València \\ Instituto de Investigaciones Históricas. UNAM
}

\section{RESUMEN}

Este artículo analiza los cuatro sermones publicados sobre la coronación del militar Agustín de Iturbide como emperador del Imperio mexicano, que tuvo lugar en la catedral metropolitana el 21 de julio de 1822. A través de dichos documentos se estudian los referentes político-culturales y religiosos que manejaron los autores eclesiásticos a la hora de legitimar al nuevo emperador y explicar el proceso que había llevado hasta su coronación. Las opiniones que sostuvieron permiten un acercamiento a las interpretaciones que realizaron sobre la independencia del país, así como al modelo de gobierno que idearon. También se observan las pretensiones de buscar un encaje privilegiado para la Iglesia en el Imperio, tratando de evitar tentativas regalistas.

PALABRAS CLAVE: Agustín de Iturbide; Imperio mexicano; independencia; coronación; sermones.

\section{THE CORONATION OF AGUSTÍN I OF MEXICO IN THE PRINTED RELIGIOUS SERMONS}

\begin{abstract}
This article analyzes the four sermons published on the occasion of the coronation of a military man, Agustín de Iturbide, as emperor of the Mexican Empire. The Ceremony took place in the Metropolitan Cathedral on July, 21th 1822. Throughout these documents we can study the political, cultural, and religious references used by the ecclesiastical authors who both legitimized the new emperor and explained the process that led to his coronation. The opinions they held bring us closer to the interpretations they made about the country's independence, as well as the government model they devised. Also, it is possible to observe the intend of achieving a privileged fit for the Church within the Empire, trying to avoid the regalist attempts.
\end{abstract}

KEY WORDS: Agustín de Iturbide; Mexican Empire; independence; coronation; sermons.

Cómo CITAR ESTE ARTículo / CITATION: Escrig Rosa, Josep. 2020. «La coronación de Agustín I de México en los sermones religiosos impresos». Hispania Sacra LXXII, 146: 525-538. https://doi.org/10.3989/hs.2020.039

Recibido/Received 16-06-2019

Aceptado/Accepted $\quad$ 10-04-2020

\section{INTRODUCCIÓN}

En este trabajo se analizan y confrontan los cuatro sermones que se conocen en impreso sobre la coronación del militar Agustín de Iturbide (1783-1824) como emperador del Imperio mexicano. El acto tuvo lugar en la catedral metropolitana el domingo 21 de julio de 1822. El primero

" Este trabajo forma parte del proyecto de investigación «Entre dos mundos. Historia parlamentaria y culturas políticas en los años del Trienio Liberal (1820-1823)» (HAR2016-78769).

1 josep.escrig@uv.es /

ORCID iD: https://orcid.org/0000-0001-8976-5998 corresponde al que pronunció en dicho momento el obispo de Puebla Antonio Joaquín Pérez, el cual no sería publicado hasta diecisiete años después. Los dos siguientes tuvieron lugar en la catedral de Guadalajara (Jalisco) el 27 de septiembre y el 13 de diciembre de ese año. Uno corrió a cargo de fray Juan de Dios María Piñera, franciscano y doctor en teología, el otro fue pronunciado por José María Hidalgo, quien había sido rector de la universidad tapatía -entre noviembre de 1813 y noviembre de 1815- y a la sazón fungía como canónigo de la catedral y gobernador del obispado. El cuarto se declamó el 12 de diciembre en la iglesia mayor de Pátzcuaro (Michoacán), a cargo del párroco Manuel de 
la Torre Lloreda, bachiller en cánones por la universidad de México. ${ }^{2}$

La importancia de los sermones a la hora de aproximarnos a la vida público-política y religiosa de los primeros momentos del México independiente ha sido resaltada por los especialistas. ${ }^{3}$ En un momento de auge de la folletería, se constituyeron en otro de los medios de comunicación que favoreció la configuración de la moderna opinión pública en los decisivos años veinte del Ochocientos. ${ }^{4}$ Su capacidad para adaptarse a las situaciones de cada momento permitía a los oradores transmitir de manera práctica los mensajes. La autoridad que confería formar parte de la jerarquía eclesiástica y el poder del púlpito y de la imprenta permitía orientar las actitudes de los receptores. Desde los distintos presupuestos ideológicos del orador, el objetivo era incidir en las conciencias colectivas y conducir o recriminar las acciones de la grey. A su vez, los sermones también contribuyeron a fomentar una identidad patriótica en la que se pretendieron reforzar los vínculos sociales a la hora de amortiguar parte de las tensiones asociadas a los cambios políticos acelerados del periodo. ${ }^{5}$ Las Sagradas Escrituras constituían un depósito de relatos moralizantes a los que acudir en busca de ejemplos y enseñanzas que podían extrapolarse a distintos momentos y realidades históricas. En algunos casos con más suerte que en otros, se trataba de una exégesis que aspiraba a insertarse en el contexto contemporáneo. No podemos olvidar, como señaló Philippe Boutry a propósito del cura romántico, que los eclesiásticos pertenecían a la Iglesia, pero no por ello dejaron de ser hombres de su tiempo que, como el resto, participaron activamente en los debates, opiniones, gustos y sensibilidades de los años en que vivieron. ${ }^{6}$ En este sentido, el análisis contextualizado de los discursos arriba mencionados, tanto en sus ingredientes teóricos como en su capacidad de incidencia sobre las prácticas políticas, puede enriquecer nuestra comprensión del Imperio mexicano. Se trata de rastrear el sustrato y los referentes político-culturales y religiosos que manejaron los autores, así como las lecturas -coincidentes o no- que realizaron sobre los acontecimientos. A través de sus interpretaciones es posible reconstruir tanto los planteamientos que sustentaron dichas cosmovisiones como los modelos de gobierno y los horizontes de futuro que idealizaron.

He estructurado las siguientes páginas en cuatro partes y unas conclusiones. La primera constituye un breve repaso del contexto que llevó hasta la coronación de Iturbide. Dar cuenta de la complejidad del periodo nos permitirá ponderar después el lugar e importancia que los autores antes

2 Pérez 1839, Biblioteca Nacional de México, colección Lafragua (en adelante BNM-CL) 445; Piñera 1822, BNM-CL 1415; Hidalgo 1822 Torre Lloreda 1823, Biblioteca Digital de la Universidad Autónoma de Nuevo León. Agradezco a Brian Connaughton que me facilitara el texto de José María Hidalgo. En el momento en que este artículo fue aceptado para su publicación he localizado otro sermón, anónimo y manuscrito, predicado el 30 de mayo de 1822 en Zacatecas con motivo de la elección de Iturbide como emperador por parte del Congreso constituyente. Sermón al pueblo de Zacatecas para que elija y jure emperador a D. Agustín de Iturbide, con el nombre de Agustín I, Biblioteca Nacional de España, Mss/20243/4. Aunque parcial, una primera aproximación al mismo en Burciaga Campos 2011.

3 Herrejón 2003, 317-342; Connaughton 2010a y 2012, 167-176. También, Terán 1998.

4 Lempérière 2003; Rojas 2003; Guerra 2014.

5 Connaughton 2001.

6 Boutry 1997. consignados otorgaron a los hechos y personajes más representativos en sus particulares recorridos históricos. Sobre esta base, en los siguientes apartados me refiero a los principales temas que se abordaron en sus sermones. En el segundo se da cuenta de los recursos utilizados para legitimar la figura del emperador, prestando especial atención a los argumentos religiosos que lo pretendían sustentar en el poder. El tercero presenta la controversia sobre el papel atribuible a Iturbide en la consecución de la independencia. Ello da paso, en cuarto lugar, a la defensa de la monarquía como modelo de gobierno idóneo para México, lo cual enlaza, a su vez, con el debate sobre la manera en que debían enfocarse las relaciones Trono-Altar. No todos los oradores coincidieron exactamente en sus exposiciones sobre estos aspectos, especialmente en lo relativo a la importancia que cabía atribuir a Iturbide en el logro de la emancipación, cómo debía manejarse en la vida política y hasta dónde resultaba aconsejable llegar para mantener el orden público. Sus particulares miras les hacían enfocar los asuntos desde un prisma u otro, aunque siempre con cautela y sugiriendo posiciones más o menos moderadas. Antes o después, está fuera de duda la incidencia de estos discursos entre un público interesado en los turbulentos acontecimientos políticos del Imperio.

Todo parece indicar que estos sermones no generaron en su momento debates públicos de entidad, muy probablemente porque las controversias se dirigieron, a partir de los últimos meses de 1822, hacia otros aspectos de la agitada vida política del Imperio, como el autoritarismo de Iturbide, las insurrecciones republicanas o la grave crisis financiera del país. En este caso, la ausencia de referencias directas a dichos escritos hace que resulte muy difícil ponderar cuál fue su recepción, aunque, de alguna forma, estos discursos debieron haber incidido entre el público interesado en los sucesos del día a día. Además, no podemos olvidar que la posterior proclamación de la República provocó que se silenciara tanto la memoria sobre lo que había supuesto esa experiencia de gobierno monárquica como los discursos que la sustentaron. Por todo ello, como antes se ha señalado, los impresos que se van a examinar tienen un valor histórico destacado: constituyen cuatro testimonios sobre las preocupaciones políticas y religiosas del momento, el desarrollo de los acontecimientos desde la revolución de 1820 y las expectativas depositadas en el reinado de Agustín I.

\section{EL CAMINO HASTA LA CORONACIÓN}

Los hechos que acabaron desembocando en la llegada de Iturbide al trono mexicano son conocidos y cuentan con una bibliografía que empieza a resultar abundante, aunque tampoco excesiva en comparación con otros momentos de la historia mexicana en el siglo XIX. El inicio del segundo periodo constitucional en la Monarquía católica, a raíz de la sublevación de Rafael de Riego en enero de 1820, impactó entre los distintos grupos ideológicos del virreinato de la Nueva España. Los liberales autonomistas, especialmente representados en los diputados mexicanos a las Cortes, entendieron que era el momento de avanzar en las reivindicaciones de autogobierno que ya esgrimieron en el tiempo de las Cortes de Cádiz. ${ }^{7}$ Los

7 Rodríguez 1993; Frasquet 2008; Frasquet 2020. Sobre los representantes americanos en Cádiz, Chust 1999. 
insurgentes continuaron apostando por la línea rupturista con el Gobierno peninsular, que habían madurado especialmente desde $1814 .^{8}$ Por su parte, los sectores conservadores de la sociedad temían los efectos -reales o ficticios- de lo que implicaban las transformaciones de la Revolución liberal. Ello se evidenciaría especialmente con los recelos que despertaron las medidas de signo secularizador que aprobaron las Cortes de Madrid. ${ }^{9}$ En medio de estas diversas orientaciones políticas, Agustín de Iturbide rubricó el 24 de febrero de 1821, en Iguala (Guerrero), un plan de independencia suficientemente amplio y ambiguo como para atraer el interés mayoritario de los individuos que integraban los grupos comentados. ${ }^{10}$

Iturbide había nacido en Valladolid de Michoacán-actual Morelia- en una familia de origen vasco. Durante la guerra civil que siguió al "grito» del cura Miguel Hidalgo destacó como estratega de la contrainsurgencia. Sin embargo, sus acciones pronto se vieron empañadas por las acusaciones de tráfico de influencias y exceso de celo militar. En 1816, el entonces virrey Félix María Calleja le relevó del mando y a partir de entonces decidió retirarse a la vida privada. Aunque no conocemos demasiado bien las redes que pudo tejer en esos años, todo apunta a que así se mantuvo hasta que, tras el cambio político que supuso la revolución de 1820, el virrey Juan Ruiz de Apodaca -conde del Venaditolo llamara en noviembre para hacer frente a las tropas insurgentes del sur acaudilladas por Vicente Guerrero. ${ }^{11} \mathrm{La}$ máxima autoridad novohispana entendió que alguien como Iturbide podía ser apropiado para mantener el orden social ante lo que suponía la concesión de nuevos indultos, la reinstalación de ayuntamientos y diputaciones constitucionales, la celebración de elecciones o la libertad de imprenta. Sin embargo, cuando tuvo noticias del Plan de Iguala inmediatamente lo consideró un traidor a la patria. ${ }^{12} \mathrm{El}$ proyecto del militar sancionaba la instauración del Imperio mexicano bajo el lema de las «tres garantías»: religión, independencia y unión. Se estipulaba que el catolicismo sería la religión exclusiva del país y que los eclesiásticos recuperarían los fueros y propiedades de que habían sido despojados por la Asamblea reunida en Madrid. México sería una «monarquía moderada» y constitucional en la que todos sus habitantes - «sin distinción alguna de europeos, africanos, ni indios»- tendrían acceso a los empleos. Además, se invitaba a que Fernando VII ocupara el trono. En caso de que este rehusara hacerlo, estaba la posibilidad de coronar a los infantes Carlos y Francisco de Paula, al Archiduque Carlos o aquel que el Congreso constituyente que se debía reunir lo acordara. Hasta que este abriera sus sesiones se crearía una Junta Gubernativa y una Regencia para encargarse de la dirección del país. ${ }^{13}$ Tras complejas negociaciones con las élites regionales, este Plan fue poco a poco aprobado por

\footnotetext{
8 Guzmán 2014.

9 Breña 2000; Ávila 2009. Sobre dicha política religiosa, Revuelta 1976. Pueden verse las diferencias respecto a las directrices más moderadas en las Cortes de Cádiz en La Parra 1985; Higueruela del Pino 2002.

10 Anna 1991, 13-38; Ávila 2004, 53-66; Frasquet 2008, 80-88; Arenal 2010, 117-134; Hamnett 2011, 301-306; Robertson 2012, 98-138.

11 Sobre esta fase se ha ocupado Moreno 2016.

12 Delgado 1948.

13 Iturbide 24 de febrero de 1821, Nettie Lee Benson Library-Latin American Collection, rare books, Newspaper 1821 SEP. 27-OCT.4 C.2.
}

las provincias del país. ${ }^{14}$ El 24 de agosto de 1821 Iturbide se reunió con Juan O'Donojú - nuevo Jefe Político de Nueva España tras la destitución de Apodaca- en Córdoba (Veracruz), donde se acordaron los tratados de homónimo nombre en los que se ampliaba lo prevenido en Iguala. Estos serían rechazados por las Cortes de la Península, lo cual dejó abierta la posibilidad de que el trono del Imperio fuera ocupado por alguien ajeno a las dinastías históricas de Europa. Finalmente, en lo que al desarrollo de los acontecimientos se refiere, el 27 de septiembre se produjo la entrada del ejército trigarante en la ciudad de México y al día siguiente se procedió a la firma del Acta de Independencia.

En los siguientes meses Iturbide continuó ocupando el centro de la vida política. Se encontraba al frente de una Regencia de cinco miembros y la Junta Provisional Gubernativa recién instalada, descartada la posibilidad de designarle también presidente, le guardó un lugar destacado para cada vez que concurriera a sus sesiones. Además, le nombró "Generalísimo de las Armas del Imperio de mar y tierra». ${ }^{15} \mathrm{~A}$ partir de entonces la tónica dominante de las sesiones fue un enfrentamiento sistemático entre la Regencia que dirigía Iturbide y una mayoría de miembros de la Junta partidarios de avanzar en la construcción del Estado-nación desde los parámetros del liberalismo revolucionario. ${ }^{16}$ Esta pugna se incrementaría cuando se reunió el Congreso constituyente el 24 de febrero de 1822, con un amplio número de diputados de orientación política liberal. Los debates sobre las fuerzas armadas acabaron llevando al máximo grado de tensión. Por un lado, se propuso prohibir que el ejército fuera comandado por los miembros de la Regencia, algo que disminuía notablemente la capacidad de mando de Iturbide. ${ }^{17}$ Por otro, los congresistas frenaron sus aspiraciones para formar un cuerpo de 35.000 soldados, al solo concederle fondos para 20.000 e impulsar la constitución de una milicia fuerte y efectiva, símbolo de la revolución. ${ }^{18}$ Ante este obstruccionismo, la noche del 18 de mayo, el antiguo batallón del general -a cuyo frente se había colocado el sargento Pío Marcha- avanzó junto a un importante contingente popular hasta la residencia de Iturbide en el Palacio de Moncada para exaltarlo al trono del Imperio. ${ }^{19} \mathrm{En}$ las sesiones de los días 19 y 21 el Congreso se vio obligado a ratificar esta elección, a pesar de las reticencias de algunos de sus miembros que trataron de ganar tiempo solicitando que se consultase a las provincias. De este modo, a través de un golpe de Estado empezaba el reinado de Agustín I, el cual se prolongaría menos de un año, pues el 19 de marzo de 1823 presentó formalmente su abdicación para dirigirse hacia el exilio en Europa.

Tal y como nos informó su principal biógrafo, la ceremonia de la coronación fue programada para el 27 de junio, pero se tuvo que posponer hasta el día 21 del mes siguiente por una indisposición de Iturbide..$^{20}$ En el ínterin, se llevaron a cabo los preparativos para la ceremonia a partir de un

\footnotetext{
14 Ortiz 2014, 247-268.

15 Diario 28 de septiembre de 1821, 11. Sobre las implicaciones políticas y simbólicas de dicho título se ha ocupado Guzmán 2019.

16 Frasquet 2008, 121-148.

17 Anna 1991, 77.

18 Mosquera 200; Frasquet 2007; Serrano y Chust 2018, 54-58.

19 Di Tella 1987; Ávila 2004, 110-114.

20 Robertson 2012, 265 y 266.
} 
programa que elaboró una comisión del Congreso. ${ }^{21}$ Los trabajos que se han ocupado del acto han mostrado la manera en que se conjugaron de una forma original el ceremonial de Napoleón I, el Pontifical Romano y los ritos propios de la tradición hispana, por lo que aquí no me detendré sobre el particular. ${ }^{22}$ El trayecto que recorrió el cortejo que acompañó al emperador estuvo engalanado con los tradicionales tapices y colgaduras. Resaltaban los revestimientos de la plaza de armas, donde el público asistente pudo ver las pinturas alegóricas que representaban el «voto nacional» y retratos de Iturbide..$^{23}$ En el interior del recinto sagrado estuvieron presentes los miembros de la familia imperial, las corporaciones citadinas, los diputados del Congreso constituyente y los obispos Juan Cruz Ruiz de Cabañas (de Guadalajara), Manuel Isidoro Pérez Sánchez (Oaxaca), Juan Francisco Castañiza (Durango) y Antonio Joaquín Pérez (Puebla). Se trató de un episodio muy particular y repleto de acciones simbólicas. Correspondió al presidente del Congreso Rafael Mangino- colocar la corona en la sien de Iturbide, recordándole en el momento de la imposición que «ese gran poder que la nación pone en vuestras augustas manos tiene por límites la Constitución y las leyes». ${ }^{24}$ Con ello los diputados querían asentar que se trataba de una monarquía constitucional en la que el poder que se entregaba provenía de la soberanía nacional, aunque se le considerara emperador por la «divina Providencia». Momentos antes, la pareja imperial había sido ungida por el prelado de Guadalajara y los congresistas José Miguel Guridi y Alcocer y Florencio Castillo, ambos eclesiásticos. De nuevo, como puede observarse, se trataba de reforzar desde un primer momento las pretensiones de soberanía del Congreso a través de la participación de dos diputados en este acto sagrado tan simbólico. Pero esta interpretación iba a entrar en conflicto con los comentarios que realizó el obispo de Puebla, a quien correspondió pronunciar el sermón principal.

Antonio Joaquín Pérez había participado en las Cortes de Cádiz y fue uno de los firmantes de la Representación y Manifiesto que los sesenta y nueve diputados serviles presentaron a Fernando VII, en mayo de 1814, solicitándole que derogara la Constitución de 1812. Su fidelidad a la causa contrarrevolucionaria sirvió para que fuera promocionado al obispado de Puebla. Con el inicio del segundo periodo liberal se retractó de sus opiniones previas y colaboró con las autoridades virreinales hasta la entrada de Iturbide en la villa angelopolitana en agosto de 1821, cuando recibió con los brazos abiertos lo que la independencia podía suponer en su particular postura ultramontana. ${ }^{25}$ Es sintomático que el sermón que pronunció el día de la coronación del emperador no se publicara hasta $1839 .{ }^{26}$ Como inmediatamente desarrollaré, de manera sutil, su alegato se mostraba

21 Proyecto 1822; Adición 1822. Ambos en BNM-CL 433 y 244, respectivamente.

22 Carbajal 2011; Hensel 2012. Con un carácter más descriptivo, Gómez-Huerta 2017. También, Mínguez y Rodríguez Moya 2011. Sobre la dialéctica continuidad-ruptura que supuso el Imperio, Zárate 1995.

23 Vázquez Mantecón 2008.

24 Citado por Frasquet 2008, 203.

25 Gómez Álvarez 1991; Pérez Memen 2011, 159 y 160.

26 Tal y como señala Alamán 1885, 482, el promotor de la impresión fue Francisco Javier de la Peña. Este fue editor del periódico El amigo de la religión, agricultura, política, comercio, ciencias y artes, aparecido entre 1839 y 1840. partidario de reforzar el poder de Iturbide frente a las otras instancias civiles, hecho que no debió pasar desapercibido por los miembros del Congreso presentes. Resulta difícil pensar que este silencio fuera una casualidad. Creo que debe ponerse en relación con el hecho de que, hasta donde tenemos noticias, solo se imprimieron tres sermones en todo el país para conmemorar la exaltación de Iturbide al trono del Imperio. Además, recuérdese, fueron predicados en la segunda mitad de 1822, meses después de la coronación, guardándose de este modo una distancia prudencial. Todo ello contrasta con el número más elevado de los que se elaboraron con motivo de la independencia. ${ }^{27}$ Las incertidumbres que suponía el inicio de esta etapa, la dudosa legalidad del encumbramiento de Iturbide, así como el enfrentamiento entre los poderes ejecutivo y legislativo que se arrastraba, probablemente influyeron en los predicadores de México, los cuales optaron por enmudecer cautelosamente a la espera del desarrollo de los acontecimientos. En cualquier caso, los cuatro sermones que entonces se enunciaron resultan suficientemente representativos como para examinar su contenido de manera transversal.

\section{ITURBIDE: UN LÍDER ESCOGIDO POR LA PROVIDENCIA}

La figura del emperador era el eje a partir del cual giraban los sermones que se realizaron con motivo de su coronación. La ausencia de una legitimidad dinástica e histórica que lo avalara llevó a que los oradores se esforzaran por suplir esta carencia con otros recursos. En el momento de la independencia los distintos publicistas -eclesiásticos especialmente, aunque no solo- se habían referido a Iturbide con distintos títulos de alabanza y comparaciones con personajes bíblicos o de la Antigüedad clásica. ${ }^{28}$ Ahora estos iban a verse reforzados, ${ }^{29}$ aunque destacaron las equiparaciones religiosas con Moisés, David, Judas Macabeo y, especialmente, Saúl. Como suele ser habitual en estos casos, las referencias no resultan casuales. ${ }^{30}$ El establecimiento de paralelismos con los reyes del Antiguo Testamento confería una autoridad innegable a aquel a quien se le colocaba a su mismo nivel. Además, a través de una secuencia de extrapolaciones, se resaltaba el carácter religioso de la empresa emancipadora y de su promotor, deslegitimando

\footnotetext{
27 Herrejón 2008.

28 Ocampo 2012, 140. También, Rodríguez Moya 2003, 211-229.

29 Estas son las menciones principales encontradas en los cuatro sermones: héroe vallisoletano, invicto héroe, héroe de Iguala, héroe libertador de la patria, libertador del septentrión, padre de la patria, americano más benemérito y benéfico, americano más fiel, ciudadano más noble, jefe más valeroso, patriota más desinteresado, militar más aguerrido, campeón más ingenioso, esclarecido jefe de la gente indiana, caudillo que Dios ha dado a su pueblo, genio superior y extraordinario, hombre sin semejante, campeón infatigable; así como referencias a Judas Macabeo, Salomón, David, Josías, Josué, Alejandro, Moisés, Caleb, Julio César y George Washington. A los pocos días de producirse la elección de Iturbide como emperador, fray Luis Carrasco insinuó que dicho militar se había propuesto redimir al pueblo mexicano, acción que le acercaba a lo que en su día realizara Jesucristo. Carrasco 25 de mayo de 1822, 8, Biblioteca de Colecciones Especiales «Elías Amador» (Zacatecas), no de control: 480317.

30 Una muestra de estos usos la encontramos en O'Hara 2018. Semejantes recursos fueron utilizados para sustentar la restauración de Fernando VII en 1814, como puede verse en Moliner 2004; La Parra 2014; Rújula 2014; Alonso 2015; Escrig Rosa 2020.
} 
al Gobierno peninsular por impío. Del mismo modo que Moisés lideró la liberación del pueblo hebreo, Iturbide se encargó de promover la ruptura política con la Península. Las virtudes religiosas de David se proyectaban sobre el emperador para presentarlo como el principal valedor de los intereses de la Iglesia. De ahí las menciones a los macabeos, quienes lucharon contra los seleucidas que trataron de imponerles el culto a los dioses griegos. En cuanto a Saúl, en hebrero su nombre significaba «deseado» y fue, según la tradición, el primer rey de los israelitas, pueblo que podía equipararse con el mexicano.

Según el obispo de Puebla, ambos pueblos, el israelita y el mexicano, no dejaron de clamar a Dios hasta que este les recompensó con un monarca adecuado a su rango. Tanto el Imperio como el portador de su corona encontraban así en las fuentes sagradas un resorte en el que asentarse con bases sólidas. Ahora bien, la segunda parte de la narración bíblica sobre Saúl entrañaba una lección que no pasaba por alto Antonio Joaquín Pérez, a pesar de que la adaptó a sus intereses. Según la costumbre, este soberano fue reprobado por la Providencia cuando abandonó los dictámenes de la religión y obró conforme a sus inclinaciones personales. En la exégesis del prelado el énfasis se ponía en la conducta del pueblo israelita. Este recibió como castigo el mando de semejante rey por haber antepuesto «un gobierno meramente humano al teocrático que los profetas habían ejercido». La misma comunidad que imploró un monarca ahora renegaba de él. Semejante actitud, desde luego, no convenía a los mexicanos. Iturbide había sido colocado en el trono por Dios para retribuir sus anteriores sacrificios y precaverlos de los desastres que les amenazaban. Su obediencia debía ser conforme a los dictámenes de la religión. Esta enseñaba que la unión de voluntades en torno a un centro común era lo más beneficioso para cualquier país. Actuar solo por intereses particulares llevaría el país a la división y anarquía. Como se observa, el obispo hacía recaer sus advertencias sobre el pueblo. Ello, teniendo en cuenta el momento y el lugar en el que lo decía, bien podía interpretarse como un aviso a los miembros del Congreso al que, de alguna manera, entendía que representaban. La elección de Iturbide para ocupar el solio imperial sería beneficiosa siempre y cuando se correspondiera con fidelidad por parte de aquellos que le habían nombrado y apoyado. Al monarca le aconsejaba en este momento de su discurso que no fuera «disimulado» como Saúl ni excesivamente opresor a la hora de hacerse respetar. ${ }^{31}$ Un poco más adelante se verá que el ejemplo bíblico le serviría también para reconvenirle respecto al trato que debía mantener con la Iglesia.

De una u otra forma, existió un consenso bastante amplio entre los oradores a la hora de señalar que Dios había elegido a Iturbide como emperador. El obispo angelopolitano hablaba de un "regalo del Omnipotente», el padre Piñera aseguraba que en su frente estaba grabado «el sello de su divinidad", y tanto el Dr. Hidalgo como Torre Lloreda acudían a las palabras con las que el profeta Samuel presentó a Saúl ante los israelitas: «bien veis al que eligió el Señor, y que no hay uno que le sea semejante en todo el pueblo». ${ }^{32}$

31 Pérez $1839,6,7$ y 15.

32 Ibídem, 11; Piñera 1822, 3; Hidalgo 1822, 6; Torre Lloreda 1823, 20. En un añadido a su sermón sobre la independencia, fray José Ortigosa sacralizó la elección de Iturbide como emperador criollo
Este realce tenía la virtud de ligar el destino de Iturbide a la voluntad de la Providencia. De este modo, se podía interpretar que si el emperador era el designado para dirigir el Imperio su gobierno estaría colmado de aciertos. Al mismo tiempo, la separación con España se tornaba legítima en tanto que había sido auspiciada por Dios a través del brazo ejecutor de aquel a quien escogió entre todos los novohispanos. Estas lecturas teológicas permitían suplir parte del miedo a lo desconocido que implicaba la independencia. Si los héroes bíblicos que también fueron seleccionados por el cielo consiguieron culminar sus acciones redentoras, los mexicanos no debían temer por el mañana, pues se encontraba igualmente respaldado por esa fuerza trascendente. Estos avales convertían a la empresa emancipadora en un proyecto de futuro. ${ }^{33}$

A la hora de afianzar la posición de Iturbide se recurrió también al lenguaje paternalista. La metáfora de la familia unida debía encontrar su correspondencia con la armonía social de los miembros que integraban la nación. El emperador ocupaba la cúspide de ese entramado y se encargaba de regular las relaciones a través de su magnanimidad, del mismo modo que aconsejaba a sus vástagos. Las relaciones entre el monarca y sus vasallos se enfocaban desde el prisma del amor y el afecto porque se entendía que solo a través de una amistad sincera podrían surgir lazos de ayuda recíproca. Según fray Juan de Dios María Piñera:

[Iturbide] se presenta a sus vasallos, como a sus propios hijos, accesible, afable, amigo de ver a todos, atento a oír a todo el mundo, y sacar del corazón de los hombres la verdad, que regularmente se oculta a los reyes, y entre la multitud de los pueblos vive tan seguro, como un buen padre lo está en su casa, rodeado de su familia, mientras el despótico en medio del reino más dilatado es un ente absolutamente solitario: manda a sus vasallos; pero sus corazones están distantes del suyo.

Al igual que Julio César, añadía, eran estos sentimientos de complicidad los que le llevaban a preferir el nombre de padre al de monarca. ${ }^{34}$ En este sentido, la nueva monarquía se legitimaba también a través de unos dispositivos retóricos y simbólicos que, salvando las distancias, hundían sus raíces en la larga tradición hispana de la figura del rey-padre..$^{35}$ Ello se veía reforzado por la búsqueda de un consenso cultural en torno a los valores de la religión. Tomando como directriz los textos Sagrados, el Dr. Hidalgo recordaba que este afecto del emperador hacia sus súbditos debía corresponderse con el mismo respeto que los hijos profesaban a sus progenitores. De ahí extraía que el pueblo no podía sustraerse de la obediencia a su superior porque el poder que este ostentaba procedía de la Providencia. Conspirar contra la autoridad del emperador era enfrentarse al mismo Dios. Solo

al equipararla con las órdenes que Moisés dictó al pueblo de Israel: «Establecerás aquel que escogiere el Señor Dios tuyo del número de tus hermanos. No podrás hacer rey a hombre de otra nación, que no sea tu hermano» (Deuteronomio 17:15). Ortigosa 1822, 4, Biblioteca Franciscana (en adelante BF) (Cholula, Puebla), clasificación local: COCY 2343.

33 Sobre la dimensión religiosa de la independencia, Connaughton $2010 b$.

${ }^{34}$ Piñera 1822, 16 y 17. Sobre el significado político del amor y la amistad durante la modernidad en el mundo ibérico pueden verse Cardim 1999, 21-57; Fernández Albadalejo 2007, 71 y 72.

35 Elliot 2004. 
la paciencia podía utilizarse como instrumento de defensa, esperando que sus excesos fueran juzgados en la otra vida. ${ }^{36}$

Para Antonio Joaquín Pérez, Iturbide se presentaba revestido de las cuatro virtudes que se esperaban de los «héroes modernos», a saber: «la piedad cristiana, la civilidad ilustrada, el valor denodado y la política más consumada». Cada una de ellas era objeto de un examen particular por su parte. La primera se presentaba por oposición a las críticas que los filósofos modernos realizaban a la religiosidad, la cual equiparaban con lo pusilánime y falto de vigor. Por el contrario, esta era vinculada por el prelado con la fuerza y el heroísmo cuyos ejemplos habían dado tantos soberanos en los Evangelios. La fe resultaba el mejor apoyo del que podía servirse la familia imperial para que su reinado prosperara. A continuación, consideraba que Iturbide había sabido combinar lo mejor de su tierra natal con los aventajamientos traídos del exterior. El resultado era una formación que le hacía capaz de desempeñar cargos como militar, hombre de Estado, magistrado o economista. Todo ello, en tercer lugar, se puso de manifiesto en la gallardía mostrada en las batallas que libró. Había sido alabado en las declaraciones realizadas en su día por virreyes y militares como Ciriaco de Llano, José de la Cruz, Francisco Xavier Venegas, Francisco Novella, Calleja, Apodaca, o el entonces gobernador español en San Juan de Ulúa (Veracruz), José Dávila. Todos eran realistas defensores de la unidad de la Monarquía católica y esperaba que, cuando contaran en la Península cómo habían perdido México, recordaran las transacciones pacíficas que progresivamente fueron laureando a Iturbide:

Aquí estamos, dirán a su corte, los que cediendo a la fuerza moral, y respetando después la física, no pudimos conservar para España, los vastos dominios que estábamos encargados. Nuestras huestes uniformadas, armadas y pagadas, eran formidables, así como las amenazas y el terror que difundíamos por todas partes: entretanto que nuestro competidor, lleno de jovialidad y de dulzura, universalmente convidaba a la paz y se dirigía a su término con un puñado de hombres inermes, desnudos, y por lo común famélicos. [...] jornadas incomprensibles, reiteradas intimaciones, negociaciones pacíficas, capitulaciones honrosas lo fueron coronando de triunfos ... ${ }^{37}$

Según el prelado, las tropas españolas eran en todo superiores a las que Iturbide fue poco a poco organizando. Aún así, la victoria había sido para aquel que abanderaba la causa justa y protegida por Dios. Frente al uso de la fuerza que unos se empeñaban en sostener, el autor del Plan de Iguala fue capaz de ganarse el apoyo de los mexicanos a través de pactos y acuerdos. De ahí que, en cuarto lugar, Pérez insistiera en sus dotes políticas para la negociación. Recordaba que los conquistadores del pasado sometieron los pueblos por las armas, pero que él había sido capaz de elevarse por encima de semejantes procedimientos. La divisa de su campaña fue evitar el derramamiento de sangre y mantener la paz en el territorio, tratando de evitar una nueva guerra civil. ${ }^{38}$ Necesariamente, estas consideraciones nos llevan a ponderar el grado de implicación que los oradores atribuyeron al emperador en la consecución de la independencia.

\footnotetext{
36 Hidalgo 1822,26 y 27.

37 Pérez 1839, 16-18.

38 Ibídem 19.
}

\section{¿QUIÉN LOGRÓ LA EMANCIPACIÓN?}

Como he comentado al principio, uno de los puntos en los que se perciben sensibles diferencias en los sermones que se están analizando es aquel en el que los cuatro eclesiásticos entraron a valorar el papel de Iturbide en la fase que llevó hasta la ruptura con España. El obispo Pérez, el Dr. Hidalgo y el padre Piñera insistieron en la dirección indiscutible del militar. De ahí que el último considerara que tras su elección como emperador «todo esta[ba] ya acabado». Se trataba del cierre de un ciclo de incertidumbres. Aunque evitando cualquier declaración tajante, el sermón de Manuel de la Torre Lloreda fue el que planteó un escenario en el que podía leerse entre líneas que el protagonismo no recaía de manera exclusiva en él. Muy probablemente ello se deba a que dicho párroco también se consideraba de algún modo partícipe del proceso. En 1809 había colaborado con los conspiradores de Valladolid para tratar de establecer un gobierno alternativo al mando virreinal. ${ }^{39}$ Aunque entonces el horizonte de este grupo era el autogobierno y no la independencia entendida como ruptura política absoluta, a la altura de 1822 Torre Lloreda vinculaba ambos presupuestos. Todo apunta a que su objetivo era retrotraer los orígenes de la empresa emancipadora de Iturbide hasta las primeras muestras de disconformidad con la autoridad peninsular que tuvieron lugar, especialmente, a partir del derrumbe institucional de la Monarquía católica a raíz de la invasión napoleónica en 1808. De esta forma, podía afirmar que Iturbide completó una empresa que ya rondaba en la cabeza de los mexicanos desde hacía tiempo: "aunque excitados por el héroe de Iguala del letárgico sueño en que yacíamos, y a merced del luminoso plan, mirábamos ya rotas las dobladas cadenas». Afirmaba que el recién nombrado emperador había sido el adalid de la independencia y que por eso le correspondía ceñir la corona, pero dejaba abiertos dos resquicios. Por un lado, que la emancipación, como acabo de consignar, se debía al "esfuerzo» conjunto de los mexicanos. Por otro, que el Plan de Iguala no hubiera sido elaborado de manera exclusiva por parte de Iturbide. ${ }^{40}$ La historiografía ha demostrado que la insinuación de Torre Lloreda era cierta, pues el emperador entregó su proyecto a terceros para que lo mejorasen. ${ }^{41}$ De hecho, en su momento circularon dos versiones del mismo en las que se observan claramente las diferencias entre el borrador menos elaborado y la versión oficial. ${ }^{42}$ Andando el tiempo, Iturbide negaría en sus Memorias que nadie más que él hubiera intervenido en su diseño: «Formé mi Plan conocido por el de Iguala; mío porque solo lo concebí, lo extendí, lo publiqué, y lo ejecuté». ${ }^{43}$ Esta convicción fue la que esgrimió de manera recurrente durante su reinado para justificar la deriva autoritaria de sus acciones de gobierno, las cuales le llevaron incluso a clausurar el Congreso constituyente que le había elegido emperador. ${ }^{44}$

\footnotetext{
39 Herrejón 2010, 80. También, Sánchez Díaz 2006.

40 Torre Lloreda 1823, 9, 17 y 18.

41 Véase, por ejemplo, la carta que envió a Juan José Espinosa de los Monteros desde Teloloapan (Guerrero) el 25 de enero de 1821, recogida en Cuevas 1947, 174 y 175.

42 Arenal 2010, 100-115.

43 Iturbide 1823, 143.

44 Justificó la disolución «como responsable a perfeccionar la obra que comencé, y la nación por su voto general me confió». Iturbide 31 de octubre de 1822, 922-924.
} 
Estas consideraciones del cura de Pátzcuaro deben ponerse en relación con sus opiniones sobre la insurgencia y el papel que le atribuía en el transcurso histórico descrito. Las simpatías que Torre Lloreda manifestó hacia los grupos autonomistas parece que no se tradujeron en un apoyo al movimiento que lideró inicialmente Miguel Hidalgo, especialmente cuando esté recurrió desde muy pronto a la violencia contra los «gachupines» para alcanzar sus objetivos. ${ }^{45}$ Este párroco consideraba apropiado que se rindieran homenajes a los «primeros héroes» que dieron el grito de la libertad. Sin embargo, a su juicio, no podía llegarse más lejos en su exaltación porque sumieron el territorio en una situación tan anárquica que muchos pensaron en que resultaba mejor "volver a sus cadenas». En 1810 hubiera sido preciso que alguien de «mediano talento» hubiera formado un plan capaz de dirigir a la "gran masa conmovida» que ya era favorable a la independencia. Esta persona, continuaba, «habría podido, sabiendo economizar la sangre y los tesoros, y jugar los resortes políticos, llevar hasta el cabo una empresa, que hacían fácil entonces los sobrados recursos, y las más favorables circunstancias». Por el contrario, los insurgentes fueron los responsables de la decadencia económica, moral y política del virreinato. Solo Iturbide fue capaz de reconducir esta empresa y llevarla a buen puerto desde el orden y la tranquilidad:

Dígase si se quiere, que el plan pudo ser hecho por uno, o muchos sabios, o que él ha sido la obra de la reflexión y del tiempo, que han notado las faltas en que se incurrió en el principio. Pudo bien ser así; más es preciso confesar, que nuestra independencia no fue el efecto de ingeniosas teorías, sino el resultado feliz de un esfuerzo valiente, constante y eficaz, y que si el plan se pudo combinar por uno, o mil ingenios, no pudo ejecutarse por otro que Agustín, que ha sabido reunir, como era necesario, el celo al talento y la persuasión con la fuerza. ${ }^{46}$

Esta alocución se estaba realizando en un contexto sobre el que habían tenido lugar arduas discusiones a propósito del lugar que debían ocupar la insurgencia y sus líderes en las conmemoraciones patrias. Los simpatizantes del movimiento que acaudilló inicialmente Hidalgo querían que se festejaran momentos señalados como el 16 de septiembre, día en el que se inició la rebelión. Iturbide y sus allegados pensaban que era mejor rememorar las fechas que tenían que ver con aquello que había ocurrido a partir de conocerse el Plan de Iguala. A su parecer debía evitarse que ambos periodos se confundieran. Los hechos de 1821 no tenían nada que ver con los de 1810, más allá de haberse abierto el camino de la liberación. De hecho, cuando el historiador Carlos María Bustamante publicó una incipiente colección de documentos sobre la independencia en la que apuntaba que Iturbide se había arrepentido de haber perseguido a los insurgentes, el militar le conminó a retractarse a comienzos de 1822, porque, aseguraba, nunca iba a disculparse «de haber obrado bien y dado caza a pícaros ladrones». ${ }^{47}$

Para el obispo de Puebla, Iturbide fue el director exclusivo de la empresa emancipadora. Veía que algunos

45 Landavazo 2009; Herrejón 2014.

46 Torre Lloreda 1823, 14-16

47 Citado por Ávila 2004, 170. Sobre estas disputas, Garrido Asperó 2001. contribuyeron a ella, pero al final «se lo dejaron todo» a él. A partir de entonces se había ocupado personalmente de la completa dirección política y militar del país: instaló la Junta Provisional Gubernativa, presidió la Regencia, asumió los cargos de Generalísimo y Almirante, propuso un beneficioso proyecto de convocatoria de Cortes que fue alterado -para su disgusto- por los diputados y constituyó la Orden Imperial de Guadalupe. En lo que a los militares se refiere, les premió con distinciones, formó nuevos reglamentos e, incluso, renunció a su sueldo y propuso una reestructuración de los fondos públicos para aumentar el erario nacional. Todo ello -concluía el prelado- tuvo lugar en un momento en el que se precisaban caudales para mantener las tropas defensoras del Imperio. ${ }^{48}$ Semejante repaso debió hacer reflexionar a más de uno de los asistentes al acto de coronación sobre la situación en la que se encontraban y el peligro que podía suponer continuar con esta dinámica cesarista. El prelado realizaba con conciencia este examen y se inclinaba por reforzar la autoridad del emperador, como se desprende de dos acusaciones. Por un lado, la que realizaba a la Junta por no haber acatado sin renuencia el plan de convocatoria de Cortes que propuso Iturbide. Según decía, el general tuvo la "desgracia de que no todos correspond[ieran] a su confianza» en las reuniones que entonces se mantuvieron. ${ }^{49}$ Por otro, respecto al tema de los caudales que había tratado

48 Pérez 1839, 16-20. El obispo de Puebla estaba en este punto explotando la buena acogida que tuvo entre los partidarios de Iturbide sus esfuerzos en la promoción del ejército. En la sesión del 11 de marzo de 1822, el Congreso constituyente presentó un plan de hacienda que reducía el sueldo del conjunto de los empleados públicos, a excepción del de Iturbide, su padre y la viuda de O’Donojú. Iturbide solicitó que también se le aplicara dicha reducción o que, de otro modo, se procediera a exentar los salarios de todos los militares. Finalmente se le aplicó un descuento del $20 \%$ a su sueldo, aunque, en agosto de 1822 , una vez fue proclamado emperador, decretó que a los militares no se les descontara nada. Es más, a finales de ese año, se presentó el presupuesto para el siguiente ejercicio económico. De un total de 20.328.740 pesos previstos para 1823, a la Casa Imperial se la dotaba con 1.500 .000 y al Ministerio de Guerra y Marina con 9.759.530, de modo que entre ambos sumaban más de la mitad del total presupuestado. De hecho, la partida prevista para la Casa Imperial iba a suscitar fuertes críticas, hasta el punto de que el 14 de diciembre la Gaceta del Gobierno Imperial de México se vio obligada a salir en defensa del emperador, asegurando que «todos vemos que no se gasta ni la décima de lo que gastaban los reyes de España». Más adelante Iturbide aseguró que tenía pensado destinar la tercera parte de lo asignado «para formar un banco que sirviese de fomento a la minería, ramo principal de industria de aquel país; y que por las convulsiones pasadas se halla muy arruinado». Obtengo estos datos de: Actas del Congreso constituyente mexicano 11 de marzo de 1822, 60-61; Actas de la Junta Nacional Instituyente 16 de diciembre de 1822, 42-44; Gutiérrez Casillas 1977, 301 y Anna 1991, 76 y 78.

49 Su propuesta para la formación del Congreso planteaba la división del legislativo en dos Cámaras, alejándose de lo prevenido en la Constitución española de 1812 que entonces estaba vigente. Se trataba de un proyecto poco claro que basculaba desde la representación individual a la funcional o corporativa. A su juicio, la «representación nacional» estaría correctamente formada por 18 eclesiásticos, 10 labradores -dueños de fincas y arrendatarios, no jornaleros-, 10 mineros, 10 artesanos, 10 comerciantes, 9 militares, 24 empleados públicos, 18 literatos -entiéndase abogados-, 2 nobles y 19 representantes del pueblo -es decir, aquellos que no pertenecieran a ninguna de las otras «clases»-. Cada uno de estos grupos se elegiría por criterios distintos. Iturbide 8 de noviembre de 1821, British Library 9770.k6. Sobre los debates del momento pueden verse, Ávila 1999; Rodríguez 2002; Pani 2003. 
de destinar a la protección del país. Esto muestra un aspecto que llevó a acalorados debates en el seno del Congreso entre el 13 y el 18 de mayo de 1822; me refiero a la cuestión de las tropas militares que he mencionado al inicio. Recuérdese que mientras Iturbide era partidario de aumentar el número de efectivos en el ejército, los diputados liberales veían en las milicias nacionales el instrumento más adecuado para llevar adelante la revolución. Para Iturbide y sus seguidores los milicianos no estaban en condiciones de enfrentarse a los ejércitos españoles y salvaguardar la independencia. El desenlace del enfrentamiento fue el golpe de Estado por el que Iturbide fue impuesto como emperador al Congreso. La correspondencia, desde luego, estaba clara para Antonio Joaquín Pérez: el ejército aupó a Iturbide, el pueblo repitió este sentimiento y el Congreso, sencillamente, fue el que, "con maduro acuerdo", lo sancionó. ${ }^{50}$ Insisto en que estas palabras fueron pronunciadas delante de los diputados que lo habían elegido en nombre de la soberanía nacional. El disentir de pareceres entre estos y el prelado era más que evidente.

La interpretación del Dr. José María Hidalgo insistía más en el carácter providencial de la elección imperial. Como se ha apuntado antes, su mirada hacía que toda resolución dependiera en última instancia de la voluntad de Dios. Los seguidores de la "orgullosa filosofía» veían la coronación como un fruto de la mera casualidad, pero los católicos mexicanos sabían que no se trataba de un «movimiento irreflexivo», sino de un voto unánime dirigido por una fuerza superior: «El cielo pues lo elige, el ejército y el pueblo mexicano lo proclama, la nación lo acepta y saluda por su monarca y emperador, y la religión exige y reclama nuestro reconocimiento a tan señalado beneficio». Coincidiendo en este punto con el obispo Pérez, el papel de los diputados en todo el proceso quedaba relegado a un plano secundario. La capacidad de mando de los reyes no provenía de la soberanía nacional, sino directamente de Dios, única fuente de autoridad. Se trataba de una Providencia que todo lo tenía previsto:

El cielo, o naciones todas del orbe, os permite que os inventéis un género de gobierno; pero entended que los decretos de la Providencia habían ya previsto y prevenido vuestras sabias disposiciones. Vosotras como libres y dóciles os elegisteis al soberano que él os había destinado, y para revestirlo de su autoridad esperaba vuestro consentimiento y elección; y luego estampó en él el sello de la Divinidad. Ved ahí ya no al rey que os hicisteis, sino al rey que el cielo os dio: vosotras fuisteis la ocasión de su potestad, no el origen de su poder: [...]. No lo elevó vuestra mano al Trono, sino que él fue colocado en el Trono del mismo Dios. ${ }^{51}$

De acuerdo con este esquema del origen del poder, para el Dr. Hidalgo los principios jurídicos y legales de una nación católica como México debían regirse por los dictámenes contenidos en las Sagradas Escrituras. En ellas se recogían títulos que descubrían a sus exégetas «un no sé que de divino en la frente de los monarcas». Estos estaban situados entre Dios y los pueblos y actuaban como un «obispo fuera de la Iglesia» en la conservación del orden prescrito desde

\footnotetext{
50 Pérez 1839, 6. De la misma opinión era Piñera 1822, 9.

51 Hidalgo $1822,6,7$ y 24.
}

las alturas. Por tanto, en el soberano encontraban sus súbditos «la imagen visible de Dios». Los reyes eran una potestad revestida de una autoridad suprema y trascendente a la que se debía obedecer. Desde los argumentos de la más rancia tradición antiilustrada, aseguraba que los falsos filósofos y pseudo-políticos podían discutir con sus «invenciones y sutilezas» sobre los orígenes de la soberanía y los límites que cabía establecer a un sistema para evitar el despotismo y la anarquía, pero los católicos tenían a la religión como guía por encima de esas disquisiciones fruto de la «ciega y soberbia razón humana». Con estas reflexiones, no sorprende que Iturbide fuera presentado por este eclesiástico como un prohombre revestido de todas las virtudes religiosas. Asentaba que este militar se decidió a intervenir tras observar el estado de abatimiento en el que se encontraba la Iglesia, como resultado de los decretos de las Cortes de España y de los planes descristianizadores de sofistas como los «Bayles, Helvecios, Voltaires, Rousouos y Raynaldos». Su objetivo no fue otro que conservar el catolicismo en su estado más puro para que México brillara como un «nuevo Israel de la Ley de Gracia». De ello, recordaba, dio muestras Iturbide en la carta que dirigió al obispo Cabañas, el 24 de febrero de 1821, cuando le invitó a unirse a su proyecto. Dicha misiva fue impresa y ampliamente difundida por el territorio con el fin de demostrar el carácter religioso de la empresa y de su autor. En ella el militar asentó que «se ha de mantener la religión sacrosanta en Nueva España pura y sin mancha, o no ha de existir Iturbide». ${ }^{52}$ De acuerdo con el Dr. Hidalgo, a partir de entonces dicho militar se había convertido en el elegido para ceñir la corona imperial. En una de sus manos portaba el "ramo de verde oliva» para convidar a la paz, pero en la otra relucía la espada con la que Dios le encargaba concluir el proyecto para el que le había destinado. Esta arma era el instrumento con el que la Providencia confiaba en sus reyes el combate sin cuartel, en la tierra, a los secuaces históricos de la fe y del orden político. Se trataba de una «espada cuya fuerza es del cielo: en cuya punta está el terror y espanto de los enemigos de la religión y de la patria, y con ella mantendrá seguros los altares y los tronos, y rebatirá el furor de los enemigos de todo lo bueno"..$^{53}$

\section{LA MONARQUía MODERADA DE AGUSTÍN I Y SUS RELACIONES ESPERADAS CON LA IGLESIA}

Un tercer aspecto que encontramos en estas disertaciones fue el de la conveniencia de adoptar la monarquía como régimen político idóneo para el nuevo país. Se consideraba que esta era la única forma de gobierno capaz de mantener los vínculos sociales y políticos. Para Torre Lloreda, la

52 Iturbide 21 de febrero de 1821; Centro de Estudios de Historia de México-CARSO, no clasificador: 1821 ITU, no inventario: 31875 ITU, observaciones: colección Puebla. Dicho prelado correspondió a través de dos donaciones de 25.000 y 1.500 pesos para el sostenimiento de la «santa causa», tal y como nos informa Pérez Memen 2011, 160-162 y 167.

53 Hidalgo $1822,8,12,13,15,16$ y 23-27. El argumento de la espada ya lo había utilizado con anterioridad para referirse al poder del virrey Francisco Xavier Venegas. Hidalgo 1811, 52. Ello nos muestra la capacidad de adaptación contextual de los discursos eclesiásticos y sus posibilidades de reutilización en momentos distintos y hasta antagónicos. 
que encabezaba Iturbide recogía lo mejor de todos los sistemas posibles: el esplendor del imperio, la sabiduría de la aristocracia y la justicia y representatividad del republicanismo. Este "compuesto», continuaba explicando, no significaba que todos esos modelos pudieran adoptarse en ese momento en México. La república no podía funcionar en un país tan amplio y con notorias diferencias sociales, del mismo modo que cualquier solución democrática significaría inestabilidad. ${ }^{54}$ Llegaba entonces a la conclusión de que la «monarquía constitucional, o moderada» era la que mejor se acomodaba a las necesidades del país. Por eso el Imperio mexicano había sido instaurado ante los clamores de la "opinión pública», hecho que fortalecía su posición ante el mundo. Se trataba del espacio donde Iturbide se había comprometido a respetar la Constitución y a defender la libertad de la nación y los derechos de sus integrantes. Todos debían unirse al emperador para caminar juntos en una misma dirección:

Y así es, que justamente la opinión general se ha decidido por la instauración del Imperio. Sí, la opinión general: porque a excepción de algunos ambiciosos, que desean la república para enseñorearse del mando, y sancionar por leyes sus caprichos; de algún impío, que apreciaría poder dividir la opinión en los supremos magistrados, para tener lugar de introducir la indiferencia religiosa; de los inquietos, que anhelan la revolución, y de aquellos hombres malignos, que desprecian su propia ruina, por maquinar la del Imperio; todos los demás ciudadanos, o votan positivamente, o se conforman con la monarquía establecida. ${ }^{55}$

El padre Piñera era de opiniones más tajantes que el párroco de Pátzcuaro. Rechazaba los gobiernos democrático, aristocrático y absoluto. Veía con terror la posibilidad de que el pueblo asumiera el poder. Este era definido como un "monstruo», "caprichoso», «inconstante», "furioso», «irresoluto" y fácil de seducir. Tampoco le convencía el dominio de los eminentes, pues acabaría por destruir la unidad que se buscaba. En cuanto al último de ellos, temía que derivara en despotismo. Solo le quedaba como opción la monarquía moderada, única capaz de perdurar. Esta estaba avalada por la tradición, pues se trataba del modelo de gobierno «primitivo de todas las naciones sabias». Debía asentarse sobre las leyes «naturales» del país y de la religión cristiana, cuya primera base había sido puesta con el Plan de Iguala. Por ello se trataba de rodear al trono con hombres virtuosos que le ayudaran a no plegarse ante las adversidades. Simbólicamente esta imagen tenía una potente carga en la que se presentaba a la Corona como necesitada de apoyos. Esta todavía no estaba lo suficientemente asentada para hacer frente por sí sola a los enemigos con los que contaba. A través del discurso paternalista que antes se ha consignado, Iturbide era un padre que precisaba de sus hijos a la hora de vivir tranquilo en su morada. Solo a través de esta dependencia mutua podría alcanzarse la felicidad general de la nación:

54 Sabemos que tras la proclamación de la República federal, en 1824, este párroco intervino como diputado constituyente del Estado de Michoacán en la elaboración del proyecto de Constitución. Sobre el particular, García Corona 2017, 154-156. Para la adaptación de los religiosos a ese contexto, Connaughton 2005.

55 Torre Lloreda 1823, 11-14.
En el reinado de Agustín no se oirán aquellas quejas, de que el trono es inaccesible a los sentimientos: que la corte ignora las desgracias de los pueblos, y que en medio del esplendor que lo rodea, no se acuerda de los desgraciados. iQué! En su reinado no se conocerán las necesidades, y los infelices dejarán de serlo: si las hubiere, las lágrimas de nuestro emperador se mezclarán con las de su pueblo, y todo cuanto nos haga sufrir la miseria, se lo hará padecer a él mismo su gran corazón. iQué! Sus deseos sobrepujarán a su poder; sus beneficios pasarán de edad en edad, y subsistirán sin temor, de que sean sepultados, sino con el excidio [sic] del universo. ${ }^{56}$

Ante este dechado de virtudes, este fraile afirmaba que, bajo la dirección de Iturbide, en México comenzaba una verdadera «edad de oro». Esta constatación, continuaba, no era un referente utópico del pasado, sino una realidad tangible que sería reconocida por todos. El optimismo con el que se afrontaba el futuro en estos sermones tenía la virtud de proyectarse sobre un horizonte inmediato que presentaba el gobierno del emperador como el mejor de los escenarios posibles.

Ahora bien, como contrapunto, el obispo de Puebla daba cuenta de los males que podía provocar la división política. Aseguraba que en el momento previo a la coronación fue cuando se manifestaron los cuatro sectores en que se encontraba escindido el país: borbonistas, iturbidistas, republicanos y los que él denominaba como "optimistas». Todos ellos se lanzaron a la arena pública de las principales ciudades pensando que también tenían voz en el seno del ejército y el Congreso. La proclamación de Iturbide como emperador libró al país de los terribles estragos de la disolución social, en donde cada clase hubiera visto peligrar su estado y empleo. Además, estas rupturas internas solo habrían servido para presentarse ante el mundo como un país incapaz de alcanzar su prosperidad por medio de la independencia. Iturbide garantizaba el orden y la unidad por encima de las luchas partidistas..$^{57}$ El Dr. Hidalgo, a su vez, hizo notar que en el momento en el que se consumó la independencia se observaba una profunda división en México entre las opiniones de aquellos que apostaban por la democracia y los partidarios del absolutismo. Sin embargo, la monarquía basada en las Sagradas Escrituras era la más adecuada para este eclesiástico porque, al regirse por las enseñanzas de Dios, encontraba allí un ejemplo de moderación. Frente a los excesos de la liberalidad que predicaban los apóstoles de la falsa filosofía, la religión mostraba el camino de la mesura, el orden y la rectitud. De todo ello se había valido Iturbide, quien dio muestras del espíritu que le animaba al conseguir la emancipación sin derramar la sangre de los mexicanos. ${ }^{58}$

Tras haber constatado las virtudes del gobierno monárquico, algunos de los eclesiásticos repararon sobre cómo debían enfocarse las relaciones entre el Trono y el Altar. Ello nos devuelve a la comparación entre Saúl e Iturbide que antes se ha mencionado. Esta vez sí que el obispo Pérez acudió al relato canónico para recordar el final trágico del personaje bíblico reprobado por Dios al desobedecer sus leyes.

\footnotetext{
56 Piñera 1822, 11-13 y 19.

57 Pérez 1839, 12 y 13.

58 Hidalgo $1822,4,5$ y 18.
} 
La moraleja era clara: si el emperador quería disfrutar de un largo reinado debía respetar los mandatos de la Iglesia y sus ministros. ${ }^{59}$ Más directo todavía fue el padre Piñera, quien recordó a sus feligreses que todo príncipe católico estaba obligado a proteger la religión y sus ministros, conservando sus derechos y manteniéndolos en el goce de sus fueros. Los eclesiásticos, por la parte que les tocaba, contribuirían a reforzar los tronos siempre y cuando se cumplieran estos requisitos. El soberano no debía traspasar el límite de la protección bajo el pretexto de reforma, pues ir más allá significaba caer en el intervencionismo que tanto daño había hecho en boca de los sofistas del Setecientos: "Por lo que toca al príncipe, conténtese con el título de protector, [...], sin extender la mano al incensario, sin arrogarse el derecho de pronunciar sobre el dogma, de arreglar el orden del culto, y de señalar las máximas, que deben guiar a los ministros en la distribución de los bienes espirituales». Por tanto, Iglesia y Estado eran "esencialmente independientes» la una del otro, con soberanías distintas y autónomas. Entre ambos existía una "confederación» por la que se prestaban ayuda mutua, pero cada uno debía mantenerse en su esfera de actuación sin más interferencias. Este auxilio recíproco era el que les permitía garantizar el orden social y sostenerse con la dignidad que les caracterizaba:

La Iglesia protegida por la potestad civil, da fuerza a las leyes, y a la disciplina: da honor y energía a su ministerio: da esplendor exterior a su culto, y por medio de su autoridad coercitiva mantiene en nivel a su gobierno. El Estado, que solo se hace obedecer por el temor de las penas, y el horror de los suplicios, alcanza con esta santa alianza, que su poder sea venerado, como que dimana de Dios; que sean guardadas sus leyes por un principio de conciencia, [...] que el honor obligue a los súbditos a sacrificarlo todo por su engrandecimiento, y que las leyes sostenidas únicamente por la sanción temporal [...] sean robustecidas con el temor de las formidables penas de una desgracia eterna... ${ }^{60}$

La alianza entre el Altar y el Trono basculaba sobre estas bases para el fraile franciscano. Ambos saldrían beneficiados si sus acciones fueran encaminadas a reforzar al otro. De ello dependía su propia estabilidad, pues los enemigos de las instituciones tradicionales eran sabedores de sus puntos débiles. Del mismo modo, cruzar estos lindes conducía hacia funestos resultados para el mantenimiento de la estabilidad: "si se prestan mutuo socorro, y contribuyen a su esplendor, todo estará en orden en las dos sociedades; pero iay! en el momento que una de las dos potestades traspase los sagrados límites, no habrá más que turbaciones y rivalidades». ${ }^{61}$ Afirmaciones de este tipo servían para aleccionar al emperador sobre el trato que debía mantener con la Iglesia. Los eclesiásticos serían el sostén del Imperio siempre y cuando este les correspondiera salvaguardando sus intereses y posición privilegiada. El poder del púlpito y de los argumentos religiosos constituían una fuerza con la que era preciso contar. En el fondo, como puede observarse, se trataba de unos análisis que pretendían aprovechar el contexto de la emancipación para rearmar a la institución eclesiástica y buscarle un encaje ventajoso en la nueva nación.

\footnotetext{
59 Pérez 1839, 21.

60 Piñera 1822, 20-23.

61 Ídem.
}

El momento era propicio para retomar este tipo de reivindicaciones. Resultaba una prioridad dejar claro el marco de las relaciones Iglesia-Estado en un momento en el que se habían roto los lazos con el Gobierno peninsular.

Estas consideraciones tenían que ver estrechamente con la interpretación que se realizaba de los motivos que llevaron a la independencia del país. Algunos eclesiásticos argumentaron que la ruptura con España se había producido para evitar que se aplicaran en México los decretos secularizadores que impulsaron los políticos liberales desde la Península. Por supuesto, no todos los eclesiásticos compartían esta interpretación, pues la Iglesia en Nueva España/ México estaba integrada por sectores sociales e ideológicos no homogéneos, con distintas sensibilidades sobre la forma en que debían enfocarse las relaciones entre el poder político y el catolicismo, tanto desde el punto de vista institucional como puramente religioso. Las diferencias y los diversos intereses dentro del clero se pusieron en evidencia a raíz de la crisis de 1808 y, de manera todavía más clara, cuando dos años después algunos religiosos encabezaron la revuelta insurgente contra el orden virreinal. ${ }^{62}$ Los eclesiásticos contrainsurgentes, también heterogéneos en su composición, con la alta jerarquía a la cabeza, impulsaron una campaña de descrédito de los sublevados, recurriendo en buena medida a las fuentes del pensamiento antiilustrado y contrarrevolucionario. Tras la restauración absolutista de 1814 , los políticos y periodistas partidarios del sistema constitucional fueron también objeto de críticas por parte del antiliberalismo eclesiástico. Todo ello generó un sustrato intelectual que sería esgrimido por los más conservadores a partir de los sucesos revolucionarios de 1820. Entonces se diseñó una imagen de la metrópoli en la que se destacaba su corrupción moral y religiosa. ${ }^{63}$

En los años siguientes se continuaron sosteniendo estas premisas a la hora de justificar la emancipación. El Dr. Hidalgo explicaba los efectos que habían tenido los «delirios de la impiedad» sobre el continente europeo y cómo el otro lado del Atlántico había optado por independizarse antes de que se extendiera el contagio: «inundando a la Francia en lágrimas y sangre, e inficionando, a pesar de los altos Pirineos a la católica España, que arrastraría forzosamente a la inocente América al mismo precipicio si la mano invisible de la Divina Providencia no la preservara». Los falsos filósofos eran los que pretendían romper la alianza entre el Trono y el Altar para debilitar a ambos y propiciar así su destrucción. ${ }^{64}$ Las medidas de reforma eclesiástica que aprobaron las Cortes de Madrid eran el blanco del padre Piñera. Ello le permitía contrarrestar semejantes disposiciones con lo que Iturbide había revertido a través del Plan de Iguala. Recordaba así que el emperador se comprometió en el momento en que se sancionó la ruptura con España a devolver el culto a su antiguo esplendor, retornar los fueros y preeminencias de los eclesiásticos y reponer las órdenes religiosas extinguidas. Sobre la base de estos puntos solo

62 Entre otros, pueden verse distintas aproximaciones en Morales 1977; Farriss 1995; Ibarra 2010; Adame Goddard 2010; Connaughton 2014 y 2016; García Ugarte 2018.

63 Véase, por ejemplo, Santa Ana 1820-1821; BF, clasificación local: COCY 1773.

64 Hidalgo 1822, 9. 
podía esperarse que la religión realizara «progresos majestuosos» en México. ${ }^{65}$

De acuerdo a lo que se ha venido exponiendo, la emancipación cobraba en estos sermones un significado especial. No solo se trataba de la ruptura política con la metrópoli, pues también la Iglesia esperaba desprenderse de las cargas regalistas para recuperar el pleno control de su potestad. ${ }^{66}$ De ahí la insistencia de algunos por recordar al emperador que encontraría el apoyo incondicional de los eclesiásticos siempre y cuando el poder civil no se inmiscuyera en los asuntos religiosos. No obstante, sabemos que la realidad resultó más compleja que lo que ciertos religiosos teorizaron. Los problemas financieros del Imperio y las sublevaciones contra la deriva autoritaria de Iturbide llevaron a que este solicitara de manera recurrente fondos a los eclesiásticos. Algunos contribuyeron convencidos de que solo el emperador podía evitar el éxito de las insurrecciones republicanas, y con ello el triunfo de la impiedad. ${ }^{67}$ Pero otros, ante las continuas presiones del Gobierno, se mostraron poco a poco reticentes a seguir desprendiéndose de los bienes de sus iglesias. ${ }^{68}$ Además, a pesar de las reivindicaciones de autonomía que se han examinado, los eclesiásticos se iban a encontrar en una situación más precaria de la que aparentaban en sus discursos. Ello les llevó a no poder prescindir del apoyo político, lo cual se acabaría concretando en las siguientes décadas -no sin resistencias- en una progresiva supeditación a los intereses de los futuros gobiernos. ${ }^{69}$

\section{CONCLUSIONES}

El estudio de los sermones que se elaboraron para festejar la coronación de Iturbide como emperador del Imperio mexicano ha permitido aproximarnos a la manera en que fue entendido dicho acontecimiento por cuatro eclesiásticos. Los documentos analizados presentan un optimismo que necesariamente se mezcla con un tono cauteloso, escéptico incluso, ante lo que podía deparar el futuro. Fue necesario construir la legitimidad del emperador al margen de tradiciones históricas o dinásticas de las que carecía. En esa empresa, resulta innegable que los discursos religiosos desempeñaron un papel destacado a la hora de buscar los argumentos sobre los que podía asentarse su reinado. Se presentó a Iturbide como un enviado del cielo para redimir al pueblo mexicano a través de su emancipación. A pesar de que todos sabían que su elección para ceñir la corona había sido el resultado de un golpe de Estado, en estas declamaciones se insistía en el carácter providencial de la decisión. Esta podía equipararse a la de los reyes veterotestamentarios, convirtiéndose entonces en un eslabón más de la larga cadena de monarcas escogidos por Dios para cumplir sus designios. Iturbide era el nuevo padre de la patria mexicana. El lugar destacado que ocupaba dentro de la familia imperial tenía su correspondencia en el cuerpo general de la nación. Junto al respaldo del ejército, el pretendido apoyo popular

\footnotetext{
65 Piñera 1822, 23.

66 Farriss 1995, 219-233.

67 Pérez Memen 2011, 200 y 201.

68 Como recoge Bustamante 7 de enero de 1823.

69 Carbajal 2005; García Ugarte 2010; Connaughton 2012, 347 461; Rosas 2015; Mijangos 2015; Suárez Cortina 2017.
}

era el que afianzaba esta posición de acuerdo a la vieja idea de vox populi, vox dei.

El debate sobre a quién correspondía el mérito en el logro de la independencia muestra las distintas opiniones que entonces se manejaron. Es cierto que en ese momento todos acababan depositando la exclusividad del plan en Iturbide, pero una lectura atenta revela que esta interpretación aceptaba matices. Fue Manuel de la Torre Lloreda el que planteó la posibilidad de que se hubiera tratado de una empresa más amplia que el emperador se encargó de completar. Estos oradores eran muy conscientes de que el movimiento insurgente de 1810 y el que impulsó Iturbide eran de naturaleza diversa, tanto en sus objetivos políticos como en las bases sociales que lo sustentaron. Otra cosa distinta es que, de algún modo, se tratara de vincular el espíritu emancipador que ambos acabaron proyectando, pero sin llegar a confundirlos. Las lecturas que apostaban por resaltar el protagonismo del emperador pretendían vigorizar su autoridad frente a la del Congreso. Insistir en su liderazgo exclusivo era la forma de avalar las acciones autoritarias que lo habían alzado con el poder. En los sermones del obispo Pérez y el padre Piñera es donde mejor se observa esta pretensión, pues Iturbide era el actor principal en todos los hitos reseñables que habían tenido lugar desde la independencia. El propio militar se acabó convenciendo de ello y por eso se presentaba ante la opinión pública como la voz auténtica de la nación mexicana. Al erigirse en representante máximo de esa voluntad podía justificar cualquier decisión que tomara en nombre del interés general. Así fue como ordenó la detención de señeros diputados del Congreso y, a finales de octubre de 1822, decretó su cierre. La Junta Nacional Instituyente que le iba a substituir fue un órgano completamente subordinado a sus decisiones, pues él mismo se encargó de elaborar las bases que debían regirla.

A finales de ese año resultaba evidente que Agustín I actuaba desde unos presupuestos que estaban bastante alejados de la monarquía moderada que plantearon algunos de los textos examinados. No encarnó el papel de un emperador-padre ecuánime como lo presentaron los oradores. Tampoco cumplió todas las expectativas que en él depositaron los eclesiásticos respecto a la manera en que debía enfocarse la alianza Altar-Trono. Más bien actuó al margen de cualquier compromiso político contraído. La inconstitucionalidad de sus actuaciones, la militarización del orden público y la vocación centralizadora llevaron a un descontento cada vez más generalizado, incluso entre aquellos que habían contribuido a su coronación. El callejón sin salida en el que se encontraba el proyecto iturbidista se hizo patente cuando, en marzo de 1823, el emperador repuso el Congreso disuelto con los mismos integrantes. Tras su abdicación y exilio en Europa retornaría a México en julio de 1824, aunque su recorrido iba a ser efímero, pues inmediatamente fue detenido y ejecutado. La edad de oro que pronosticó el padre Piñera no pudo materializarse en esos años bajo la forma monárquica. Ello, sin embargo, no debería llevarnos a una lectura finalista del periodo, sino a tomar conciencia del momento de encrucijada en el que se vivía. Es preciso rastrear las coordenadas simbólicas a través de las que los actores del periodo se manejaron e intervinieron en la esfera público-política tratando de condicionar las acciones de los individuos. En esa tarea, los sermones, de 
larga tradición en la historia de la Monarquía católica, ${ }^{70}$ destacaron en los primeros momentos de la contemporaneidad por abrirse hacia nuevos temas y preocupaciones, convirtiéndose así, de manera más efectiva, en un instrumento de instrucción, adoctrinamiento y difusión de ideología.

\section{FUENTES PRIMARIAS}

1821. Diario de las Sesiones de la Soberana Junta Provisional Gubernativa del Imperio Mexicano. México: Imprenta Imperial de Alejandro Valdés. Reeditadas en 1980. Actas constitucionales mexicanas (1821-1824), tomo I. México: Universidad Nacional Autónoma de México.

1822. Actas del Congreso constituyente mexicano, tomo I. México: Alejandro Valdés. Reeditadas en 1980. Actas constitucionales mexicanas (1821-1824), tomo II, volumen I. México: Universidad Nacional Autónoma de México.

1822. Actas de la Junta Nacional Instituyente. Versión de 1878. Historia parlamentaria de los congresos mexicanos. México: Imprenta de J. F. Jens. Reedición de 1997 a cargo del Instituto de Investigaciones Legislativas, tomo II.

1822. Proyecto del ceremonial que para la inauguración, consagración y coronación de su majestad el emperador Agustín Primero se presentó por la comisión encargada de formarlo al soberano Congreso en 17 de junio de 1822. México: Imprenta de don José María Ramos Palomera.

1822. Adición al proyecto del ceremonial impreso en 17 del corriente para la inauguración de su S. M. I. México: Imprenta Imperial del Sr. Valdés.

Alamán, Lucas. 1885 (1849-1852). Historia de México, tomo V. México: Imprenta de Victoriano Agüeros.

Bustamante, Carlos María. Diario histórico de México, 1822-1848. Edición de 2001. México: El Colegio de México y Centro de Investigaciones y Estudios Superiores de Antropología Social.

Carrasco, Luis. 25 de mayo de 1822. Circular que el Provincial de Santo Domingo dirige a los religiosos de su Provincia de Santiago de Predicadores del Imperio Mexicano. México: Imprenta de don José María Ramos Palomera.

Hidalgo, José María. 29 de agosto de 1811. Sermón eucarístico que en la solemne función celebrada en la santa iglesia catedral de Guadalajara, por el singular beneficio del cielo, en haberse descubierto e impedido la conspiración tramada en México contra el primero y más digno jefe del reino, y contra todos los bienes ciudadanos. Dijo el doctor..., canónigo magistral de la misma iglesia, por encargo del M. I. señor brigadier D. José de la Cruz, comandante general del ejército de reserva, gobernador intendente de esta provincia, y presidente de la Real audiencia. Que lo da a luz en testimonio de su celo, y ardientes deseos de la pública tranquilidad. Guadalajara: de orden superior.

Hidalgo, José María. 1822. Sermón que en la solemne función que celebró el ilustre Ayuntamiento de Guadalajara, capital de la Nueva Galicia en la iglesia catedral de la misma ciudad el día 13 de diciembre de 1822 por la proclamación y jura de su augusto emperador Agustín Primero. Guadalajara: Imprenta Imperial de don Mariano Rodríguez.

Iturbide, Agustín de. 21 de febrero de 1821. Católicos sentimientos del señor Iturbide, expresados en su carta al señor obispo de Guadalajara. Puebla: Oficina de don Pedro de la Rosa.

Iturbide, Agustín de. 24 de febrero de 1821. «Plan o indicaciones para el gobierno que debe instalarse provisionalmente con el objeto de asegurar nuestra sagrada religión y establecer la independencia del Imperio mexicano: y tendrá el título de Junta Gubernativa de la América Septentrional; propuesto por el Sr. coronel D. Agustín de Iturbide al Excmo. Sr. virrey de N. E. Conde del Venadito». En Suplemento al número 14 de la Abeja Poblana. Puebla, 2 de marzo de 1821.

\footnotetext{
70 Herrejón 2003; Urrejola Davanzo 2017.
}

Iturbide, Agustín de. 8 de noviembre de 1821. Pensamiento que en grande ha propuesto el que suscribe como un particular por la pronta convocatoria de las próximas Cortes, bajo el concepto de que se podrá aumentar o disminuir el número de representantes de cada clase, conforme acuerde la Junta Soberana con el Supremo Consejo de Regencia. México: Imprenta Imperial de Alejandro Valdés.

Iturbide, Agustín de. 31 de octubre de 1822. «Decreto de S. M. I. comunicado por el Excmo. Sr. secretario de Estado y del Despacho de Relaciones Interiores y Exteriores D. José Manuel de Herrera, y publicado por Bando el día 31». En Gaceta del Gobierno Imperial de México del 5 de noviembre de 1822, 121, 922-924. México: Imprenta Imperial.

Iturbide, Agustín de. 1823. "Memorias que escribió en Liorna don Agustín de Iturbide». Recopiladas en 2014. Escritos diversos, 138176. México: Consejo Nacional para la Cultura y las Artes.

Ortigosa, José. 1822. Sermón que con motivo de la jura de la independencia dijo en la iglesia parroquial de N. S. de la Asunción y N. P. S. Francisco de Toluca el día 13 de mayo de 1822, el R. P. Fr. ... México: Oficina de don Mariano Ontiveros.

Pérez, Antonio Joaquín. 1839. Sermón predicado en la santa iglesia metropolitana de México el día 21 de julio de 1822 por el Excmo. e IImo. Sr. Dr. D. ... dignísimo obispo de la Puebla de los Ángeles con motivo de la solemne coronación del señor D. Agustín de Iturbide, primer emperador constitucional de México. Puebla: Impreso por Juan N. del Valle.

Piñera, Juan de Dios María. 1822. Sermón panegírico eucarístico que en honra de nuestro libertador el Sr. D. Agustín Primero emperador augusto del gran Imperio del Anahuac en su exaltación al trono y día de su nacimiento dijo... en función dispuesta por tan interesantes objetos el día 28 de agosto en la santa iglesia catedral por el señor Intendente Jefe Político Superior, interino de esta Provincia D. Antonio Gutiérrez y Ulloa. Guadalajara: Imprenta Imperial de don Mariano Rodríguez.

Santa Ana, Pedro de (fray). 1820-1821. La España agonizante con la peste de la Francia. México: Alejandro Valdés.

Torre Lloreda, Manuel de la. 1823. Discurso que en la misa de gracias celebrada en la iglesia mayor de la ciudad de Pátzcuaro el día 12 de diciembre de 1822, a consecuencia de la aclamación religiosa del señor don Agustín Primero emperador de México, dijo Manuel de la Torre Lloreda. Lo publica el Ayuntamiento Constitucional de la misma ciudad. México: Imprenta Imperial del Sr. don Alejandro Valdés.

\section{BiBLIOGRAFÍA}

Adame Goddard, Jorge. 2010. "Asimilación y rechazo en México del sistema de relaciones entre la Iglesia y el Estado contemplado en la Constitución de Cádiz». Anuario Mexicano de Historia del Derecho 22: 57-74.

Alonso, Gregorio. 2015. "Imaginando a Fernando VII, rey católico y felón». Pasado y Memoria 14: 57-77.

Anna, Timothy E. 1991. El Imperio de Iturbide. México: Alianza y Consejo Nacional para la Cultura y las Artes.

Arenal, Jaime del. 2010. Un modo de ser libres. Independencia y Constitución en México (1816-1822). México: El Colegio de Michoacán e Instituto Nacional de Estudios Históricos de las Revoluciones de México.

Ávila, Alfredo. 1999. "Las primeras elecciones del México independiente». Política y cultura 11: 29-60.

Ávila, Alfredo. 2004. Para la libertad. Los republicanos en tiempos del imperio, 1821-1823. México: Universidad Nacional Autónoma de México.

Ávila, Alfredo. 2009. «Cuando se canonizó la rebelión. Conservadores y serviles en Nueva España». En Conservadurismo y derechas en la historia de México, t. I, coordinación de Erika Pani, 43-85. México: Fondo de Cultura Económica y Consejo Nacional para la Cultura y las Artes.

Boutry, Philippe. 1997. «El cura». En El hombre romántico, edición de François Furet, 211-238. Madrid: Alianza. 
Breña, Roberto. 2000. "La consumación de la independencia de México: ¿dónde quedó el liberalismo? Historia y pensamiento político». Revista Internacional de filosofía política 16: 59-94.

Burciaga Campos, José Arturo. 2011. «Construyendo patria desde la Iglesia. Un sermón religioso en Zacatecas a favor de Agustín I». En Estado y nación en México. Independencia y revolución, coordinación de Esaú Márquez, Rafael Araujo y Rocío Ortiz, 379-394. Tuxtla Gutiérrez: Universidad de Ciencias y Artes de Chiapas.

Carbajal, David. 2005. «Un obispado para Veracruz, 1799-1846: del honor de la ciudad a la lealtad al Estado». Anuario de Estudios Americanos LXII, 1: 181-208.

Carbajal, David. 2011. «Una liturgia de ruptura: el ceremonial de consagración y coronación de Agustín I». Signos Históricos 25: 68-99.

Cardim, Pedro 1999. «Amor e amiza de na cultura política dos séculos XVI e XVII». Lusitania Sacra 11: 21-57.

Chust, Manuel. 1999. La cuestión nacional americana en las Cortes de Cádiz. Valencia: Fundación Instituto de Historia Social y Universidad Nacional Autónoma de México.

Connaughton, Brian. 2001. Dimensiones de la identidad patriótica. Religión, política y regiones en México, siglo XIX. México: Universidad Autónoma Metropolitana.

Connaughton, Brian. 2005. «Clérigos federalistas ¿Fenómeno de afinidad ideológica en la crisis de dos potestades?». En Raíces del federalismo mexicano, coordinación de Manuel Miño Grijalva et al., 71-87. Zacatecas: Universidad Autónoma de Zacatecas.

Connaughton, Brian. 2010a. «¿Politización de la religión o nueva sacralización de la política? El sermón en las mutaciones públicas de 1808-1824». En Religión, política e identidad en la independencia de México, coordinación de Brian Connaughton, 160-200. México: Universidad Autónoma Metropolitana.

Connaughton, Brian. 2010b. «Forjando el cuerpo político a partir del corpus mysticum: la búsqueda de la opinión pública en el México independiente, 1821-1854». En Entre la voz de Dios y el llamado de la patria. Religión, identidad y ciudadanía en México, siglo XIX, 99-116. México: Fondo de Cultura Económica.

Connaughton, Brian. 2012. Ideología y sociedad en Guadalajara (1788 1853): La Iglesia católica y la disputa por definir la nación mexicana. México: Consejo Nacional para la Cultura y las Artes.

Connaughton, Brian. 2014. "La búsqueda del código jurídico y la forja del canon de reforma político-religiosa: Macanaz y la tradición regalista, siglos XVIII-XIX». En Reformas y resistencias en la Iglesia novohispana, coordinación de María del Pilar Martínez López-Cano y Francisco Javier Cervantes Bello, 351-396. México: Universidad Nacional Autónoma de México.

Connaughton, Brian. 2016. «El constitucionalismo político-religioso. La Constitución de Cádiz y sus primeras manifestaciones en el Bajío mexicano y zonas aledañas». Relaciones 147: 85-154.

Cuevas, Mariano. 1947. El libertador. Documentos selectos de Agustín de Iturbide. México: Editorial Patria.

Delgado, Jaime. 1948. «El conde del Venadito ante el Plan de Iguala». Revista de Indias IX, 31/32: 957-966.

Di Tella, Torcuato S. 1987. Iturbide y el cesarismo popular. Buenos Aires: Editorial Biblos.

Elliot, John. 2004. «Rey y patria en el mundo hispánico». En El Imperio sublevado: monarquía y naciones en España e Hispanoamérica, coordinado por Manuel Chust y Víctor Mínguez, 17-36. Madrid: CSIC.

Escrig Rosa, Josep. 2020. «La construcción ideológica de la Restauración en Nueva España (1814-1816)». Historia mexicana LXIX, 4: 1493-1598.

Farriss, Nancy. 1995. La corona y el clero en el México colonial, 15791821. La crisis del privilegio eclesiástico. México: Fondo de Cultura Económica.

Frasquet, Ivana 2007. «El Estado armado o la nación en armas». En Las armas de la nación. Independencia y ciudadanía en Iberoamérica (1750-1850), edición de Manuel Chust y Juan Marchena, 111-135. Madrid y Frankfurt: Iberoamericana Vervuert.

Frasquet, Ivana. 2008. Las caras del águila. Del liberalismo gaditano a la república federal mexicana (1820-1824). Castellón: Universitat Jaume I.

Frasquet, Ivana. 2020. «México en el Trienio Liberal. Entre la autonomía monárquica y la federación imposible». En La revolución política.
Entre autonomías e independencias en Hispanoamérica, edición de Ivana Frasquet y Víctor Peralta, 189-214. Madrid: Marcial Pons.

Fernández Albadalejo, Pablo. 2007. Materia de España. Cultura política e identidad en la España moderna. Madrid: Marcial Pons.

García Corona, Nely Noemí. 2017. Entre el cielo y la tierra: la participación de los eclesiásticos en el Congreso de Michoacán durante la primera República Federal, 1824-1825. Tesis doctoral. Universidad Pablo de Olavide.

García Ugarte, Marta Eugenia. 2010. Poder político y religioso. México, siglo XIX. México: Universidad Nacional Autónoma de México.

García Ugarte, Marta Eugenia, coord. 2018. Ilustración católica. Ministerio episcopal y episcopado en México (1758-1829), vols. I y II. México: Universidad Nacional Autónoma de México.

Garrido Asperó, Ma José. 2001. «Cada quién sus héroes». Estudios de historia moderna y contemporánea de México, 22: 5-22.

Gómez Álvarez. Cristina. 1991. El obispo Pérez y la revolución de independencia. Puebla: Gobierno del Estado de Puebla.

Gómez-Huerta José. 2017. «Iturbide "el breve", primer emperador de México: el ceremonial de una coronación». Estudios institucionales IV, 7: 91-106.

Guerra, François-Xavier. 2014. Modernidad e independencias. Ensayos sobre las revoluciones hispánicas. México: Fondo de Cultura Económica y Mapfre.

Gutiérrez Casillas, José. 1977. Papeles de don Agustín de Iturbide. Documentos hallados recientemente. México: Editorial tradición.

Guzmán, Moisés. 2014. «El movimiento Trigarante y el fin de la guerra en Nueva España (1821)». Anuario Colombiano de Historia Social y de la Cultura XLI, 2: 131-161.

Guzmán, Moisés. 2019. «El Generalísimo: configuración, prácticas políticas y representación del poder supremo (México, 1810-1822)». Revista de Indias LXXIX, 275: 165-196. https://doi.org/10.3989/ revindias.2019.006

Hamnett, Brian. 2011. Revolución y contrarrevolución en México y el Perú. Liberales, realistas y separatistas (1800-1824). México: Fondo de Cultura Económica.

Hensel, Silke. 2012. «La coronación de Agustín I. Un rito ambiguo en la transición mexicana del Antiguo Régimen a la independencia». Historia Mexicana LXI, 4: 1349-1411.

Herrejón, Carlos. 2003. Del sermón al discurso cívico, 1760-1834. Zamora: El Colegio de Michoacán y el Colegio de México.

Herrejón, Carlos. 2008 (1999). «Sermones y discursos en el Primer Imperio». En Construcción de la legitimidad política en México en el siglo XIX. Coordinación de Brian Connaughton et al., 152-167. Zamora: El Colegio de Michoacán et al.

Herrejón, Carlos. 2010. "Colegios e intelectuales en el obispado de Michoacán, 1770-1821». En La guerra de la independencia en el obispado de Michoacán, coordinación de José Antonio Serrano, 53-91. Zamora: El Colegio de Michoacán.

Herrejón, Carlos. 2014. Hidalgo. Maestro, párroco e insurgente. Zamora: El Colegio de Michoacán.

Higueruela del Pino, Leandro. 2002. "La Iglesia y las Cortes de Cádiz». Cuadernos de Historia Contemporánea 24: 61-80.

Ibarra, Ana Carolina. 2010. El clero de la Nueva España durante el proceso de independencia, 1808-1821. México: Universidad Nacional Autónoma de México.

La Parra, Emilio. 1985. El primer liberalismo español y la Iglesia: las Cortes de Cádiz. Alicante: Instituto de Estudios Juan Gil Albert.

La Parra, Emilio. 2014. «Fernando VII, el rey providencial enviado de Dios». Alcores 17: 39-53.

Landavazo, Marco Antonio. 2009. «Para una historia social de la violencia insurgente: el odio al gachupín». Historia mexicana LIX, 1: 195-225.

Lempérière, Annick. 2003. "Versiones encontradas del concepto de opinión pública. México, primera mitad del siglo XIX». Historia Contemporánea 27: 565-580.

Mijangos, Pablo. 2015. The Lawyer of the Church. Bishop Clemente de Jesús Munguía and the Clerical Response to the Mexican Liberal Reforma. Lincoln: University of Nebraska Press.

Mínguez, Víctor e Inmaculada Rodríguez Moya. 2011. «Sueños de púrpura. Modelos artísticos e imágenes simbólicas del mito imperial 
en el México independiente». En Constitución, poder y representación. Dimensiones simbólicas del cambio político en la época de la independencia mexicana, coordinación de Silke Hensel, 81-120. Madrid y Frankfurt: Iberoamericana Vervuert.

Moliner, Antonio. 2004. "La elaboración del mito absolutista del "Deseado" Fernando». En Josep Fontana. Història i projecte social. Reconeixement a una trajectòria, 952-967. Barcelona: Crítica.

Morales, Francisco. 1977. Clero y política en México, 1767-834. Algunas ideas sobre la autoridad, la independencia y la reforma eclesiástica. México: Secretaría de Educación Pública.

Moreno, Rodrigo. 2016. La trigarancia. Fuerzas armadas en la consumación de la independencia. Nueva España, 1820-1821. México: Universidad Nacional Autónoma de México.

Mosquera, Ángeles. 2005. «Ejército y milicia cívica: fuerzas armadas y pugna de poderes en el primer parlamentarismo mexicano, 18211824». Secuencia 63: 99-126.

O'Hara, Matthew. 2018. The History of the Future in Colonial Mexico. Yale: Yale University Press.

Ocampo, Javier. 2012 (1969). Las ideas de un día. El pueblo mexicano ante la consumación de la independencia. México: Consejo Nacional para la Cultura y las Artes.

Ortiz, Juan. 2014. Guerra y gobierno. Los pueblos y la independencia de México, 1808-1825. México: El Colegio de México e Instituto de Investigaciones Dr. José María Luís Mora.

Pani, Erika. 2003. «Ciudadanos, cuerpos, intereses. Las incertidumbres de la representación. Estados Unidos, 1776-1787-México, 18081828». Historia Mexicana LIII, 1: 65-115.

Pérez Memen, Fernando. 2011. El episcopado y la independencia de México (1810-1836). México: El Colegio de México.

Revuelta, Manuel. 1976. "Los planes de reforma eclesiástica durante el Trienio Constitucional». Miscelánea Comillas: revista de ciencias humanas y sociales XXX, 57: 329-348.

Robertson, William S. 2012 (1952). Iturbide de México. México: Fondo de Cultura Económica.

Rodríguez Moya, Inmaculada. 2003. «Agustín de Iturbide, ¿héroe o emperador?». En La construcción del héroe en España y México
(1789-1847), coordinación de Víctor Mínguez y Manuel Chust, 211-229. Valencia: Publicacions de la Universitat de València.

Rodríguez, Jaime E. 1993. "La transición de colonia a nación: Nueva España, 1820-1821». Historia Mexicana XLIII, 2: 265-322.

Rodríguez, Jaime E. 2002. "Las elecciones a las Cortes constituyentes mexicanas». En Ensayos en homenaje a José María Muriá, coordinado por Louis Cardallaic y Angélica Peregrina, 79-119. Guadalajara: El Colegio de Jalisco.

Rojas, Rafael. 2003. La escritura de la independencia. El surgimiento de la opinión pública en México. México: Taurus.

Rosas, Sergio. 2015. La iglesia mexicana en tiempos de impiedad: Francisco Pablo Vázquez, 1769-1847, Puebla: Benemérita Universidad Autónoma de Puebla.

Rújula, Pedro. 2014. «El mito contrarrevolucionario de la “Restauración"». Pasado y Memoria 13: 79-94.

Sánchez Díaz, Gerardo. 2006. «Manuel de la Torre Lloreda: entre la ilustración novohispana y la construcción de la República». En Entre la tradición y la modernidad. Estudios sobre la Independencia, coordinado por Moisés Guzmán, 99-124. Morelia: Universidad Michoacana de San Nicolás de Hidalgo.

Serrano, José Antonio y Manuel Chust. 2018. Milicia cívica, revolución liberal y federalismo en México (1812-1846). Madrid: Marcial Pons y Universidad Michoacana de San Nicolás de Hidalgo.

Suárez Cortina, Manuel. 2017. «Religión, Estado y Nación en España y México en el siglo XIX. Una perspectiva comparada». Historia mexicana LXVII, 1: 341-400.

Terán, Mariana. 1998. "Sermones y tradiciones. Estado de la cuestión y propuestas de análisis». Caleidoscopio 3: 37-56.

Urrejola Davanzo, Bernarda. 2017. El relox del púlpito. Nueva España en el contexto de la Monarquía, según sermones de la época (1621-1759). México: El Colegio de México y Universidad de Chile.

Vázquez Mantecón, María del Carmen. 2008. «Las fiestas para el libertador y monarca de México Agustín de Iturbide, 1821-1823». Estudios de historia moderna y contemporánea de México 36: 45-83.

Zárate, Verónica. 1995. «Tradición y modernidad: la Orden Imperial de Guadalupe. Su organización y sus rituales». Historia Mexicana XLV, 2: 191-220. 